\title{
Memory and Myth at the Buffalo Bill Museum
}

\author{
Greg Dickinson, Brian L. Ott, \& Eric Aoki
}

Few places tell the myth of the American frontier more vigorously than the Buffalo Bill Museum does in Cody, Wyoming. Traveling to the museum through the 'Western' landscape of Wyoming into the foothills of the Rockies prepares visitors for the tale of Western settlement. This narrative, which works to secure a particular vision of the West, draws upon the material artifacts of Cody's childhood and his exploits as scout, Pony Express rider and showman. The museum retells the story that Cody first told to millions at the turn of the twentieth century in his Wild West arena show. In this paper, we argue that the museum privileges images of masculinity and Whiteness, while using the props, films, and posters of Buffalo Bill's Wild West to carnivalize the violent conflicts between Anglo Americans and Native Americans.

Keywords: Public Memory; Museums; The American West; Buffalo Bill Cody; Whiteness; Masculinity; National Identity; Native Americans

\section{Introduction}

The story of the American frontier is a foundational myth. It both reveals how Americans view themselves as 'Americans' and informs the actions they take on a local and global stage (Slotkin, 1992, p. 10). Like all national (hi)stories, it is a dynamic myth, adapting to the demands of an age and the psychological needs of those who would tell the story as their own. It is a story that first began to be told in the eighteenth century, and one that took on particular importance in the late nineteenth century when Frederick Jackson Turner (1994) first read his paper, 'The Significance of the Frontier

\footnotetext{
Greg Dickinson and Brian L. Ott are Associate Professors in Speech Communication at Colorado State University. They are co-first authors of this paper. Eric Aoki is also an Associate Professor in the same department. Correspondence to: Greg Dickinson, Department of Speech Communication, 219 Eddy Building, Colorado State University, Fort Collins, CO 80523-1783, USA.Tel: (970) 491 6893. Email: Greg.Dickinson@colostate.edu. An earlier version of this paper was presented at the 2002 convention of the National Communication Association in New Orleans, LA. The authors wish to thank Aimee Carillo Rowe, Carole Blair, and the Colorado State University Speech Communication writing group including Karrin Vasby Anderson and Carl Burgchardt for their contributions to this paper.
} 
in American History', to an audience of nearly 200 historians gathered in Chicago during the World's Columbian Exhibition:

Up to our own day American history has been in large degree the history of colonization of the Great West. The existence of an area of free land, its continuous recession, and the advance of American settlement westward, explain American development. (p. 31)

But it was another figure of that time, William Frederick 'Buffalo Bill' Cody, who popularized the story of the frontier. Born in Iowa territory in 1846, William Cody was many things - a frontiersman, civilian scout, Pony Express rider and hunting guide. He did not become a well-known public figure, however, until the early 1870 s when pulp novelist Ned Buntline transformed Cody into the legendary hero, Buffalo Bill. The dime novel press was a key force in fostering national and international interest in the West (Kasson, 2000, p. 201), and 'More dime store novels were written about "Buffalo Bill” than any other western character' (Sorg, 1998, p. xiii). Had Buffalo Bill remained merely a colorful character in dime novel fiction, then the history of the West may have been remembered very differently than it was for much of the twentieth century.

But Cody was an entrepreneur. Recognizing the public's appetite for narratives of western settlement, especially those involving clashes with Indian 'savages', he embraced the image of Buffalo Bill and 're-created himself as a walking icon' (White, 1994, p. 11). In 1883, Cody launched a carnivalesque arena show known as Buffalo Bill's Wild West, which blended his life experiences with the exploits of his mythic alter ego, Buffalo Bill, into a master narrative of the frontier. 'Fact' and 'fiction' became indistinguishable (Slotkin, 1992, pp. 81-82). Although the images of the frontier it presented were highly selective, dramatized, and romanticized, 'the Wild West ... seemed like an invitation into living history' (Buffalo Bill Museum, 1995, p. 31). A renowned storyteller and showman, Cody 'never referred to his Wild West as a show' (White, 1994, p. 7), and audiences in the United States and Europe saw the Wild West as a serious attempt to tell the history of the West (Slotkin, 1992, pp. 67-68). By the time it ended its run in 1913, 'Buffalo Bill was the most famous American of his time' (Tompkins, 1992, p. 179) and he 'typified the Wild West to more people in more parts of the world than any other person' (Lamar, 1977, p. 230).

In telling the story of the frontier, Buffalo Bill's Wild West 'defined the quintessential American hero' (Buffalo Bill Museum, 1995, p. 28) and brought 'the essence of the American West to the world' (Treasures, 1992, p. 8). With its dramatic images of untamed lands and cowboy heroes, frontier mythology is distinctly Anglo and 'American' in character, for as Will Wright (2001) asserts, the White 'cowboy represents the American idea, not just American history' (p. 2). Over the past half century, both the stories of the frontier and the key sites in which those stories are told have changed, but the frontier myth has remained a vital part of US national identity (Wright, p. 10). To gain a richer understanding of how the frontier myth is constructed in contemporary US culture, we turn to the Buffalo Bill Historical Center (BBHC) and more particularly the Buffalo Bill Museum (BBM). The BBM is, we believe, especially well suited for examining memory, myth, and their intersection, both because of its significance as a museum of Western history and its particular connection to Buffalo Bill. 
It is difficult to contest the importance of the BBHC as a key site in the construction of public memory regarding the 'Old West.' Composed of five internationally acclaimed museums (The Buffalo Bill Museum, Whitney Gallery of Western Art, The Plains Indian Museum, The Cody Firearms Museum, and The Draper Museum of Natural History), the Center encompasses over 300,000 square feet, making it the largest history and art museum between Minneapolis and the West Coast. Once described by author James Michener as 'The Smithsonian of the West' ('Buffalo Bill', 2001, p. 4), the BBHC 'is widely regarded as this country's finest western museum' (Visitor's guide). Although the whole complex certainly deserves analysis, the Center's size and complexity constrain what can be adequately addressed in one journal paper. More importantly, Buffalo Bill and the museum dedicated to his life provide the authorial voice for the entire Center and activates the central narrative of the frontier in constructing a national identity. Therefore, our analysis focuses on only the Buffalo Bill Museum, which establishes the narrative form of the Center and addresses many of the rhetorical issues raised by the $\mathrm{BBHC}$ as a whole. Based on its rhetorical invitations to collective memory and national identity, we argue that the Buffalo Bill Museum privileges images of Whiteness and masculinity, while using the props, films, and posters of Buffalo Bill's Wild West to carnivalize the violent conflicts between Anglo Americans and Native Americans.

In order to illustrate this claim, we first briefly outline the history of the museum itself. We then chart the material and symbolic ways that history museums function as rhetorical invitations to collective memory and national identity. Third, we move to an analysis of the Buffalo Bill Museum and to the specific ways it privileges Whiteness and masculinity, and carnivalizes the violent colonization of the West. Finally, we reflect upon what an analysis of the BBM suggests, not only about the construction of a particular nationalized myth, but also about the roles that White masculinity and carnivalized violence play in that myth.

\section{The Building of the Buffalo Bill Museum}

Although we do not wish to perpetuate an intentional fallacy, briefly tracing the history of the Buffalo Bill Museum and Buffalo Bill Historical Center can help clarify the ideological and economic forces that shaped the construction and function of the museum. The Buffalo Bill Museum started as little more than a local institution. Housed in a small log building designed as a replica of William Cody's TE ranch house (just outside of Cody, Wyoming), the museum was an odd collection of Buffalo Bill and Western memorabilia, taxidermied animals, historic firearms, the putative scalp of Cheyenne Chief Yellow Hair, and a display of locally produced art (Nicholas, 2002, p. 449).

From the very beginning, however, the founders of the museum had national aspirations. By 1924, sculptor Gertrude Vanderbilt Whitney (an heir to significant fortunes) had purchased better land for the museum (adjacent to the original Buffalo Bill Museum and site of the current complex), built a Buffalo Bill memorial sculpture (The Scout), and transported it to Cody using her own money (Bartlett, 1992, pp. 46-53). Her initial gift was valued at $\$ 50,000$. However, this gift was dwarfed by the support of William 
Robertson Coe, who became the institution's most important Eastern supporter (Bartlett, 1992, pp. 117-118). Born and raised in England, Coe believed that Americans took their traditions for granted (Nicholas, 2002, p. 450). Coe focused his attention and considerable financial resources to educate Americans in these traditions, and he saw the Buffalo Bill Museum as a powerful site for this pedagogy. Located in the heart of the Wyoming, a state that Coe believed was still 'fresh with the pioneer spirit' (quoted in Nicholas, 2002, p. 452), the Buffalo Bill Museum could 'tell the deep cultural stories about the West' (Nicolas, 2002, p. 459). Further funding for building the Buffalo Bill Museum itself came through the sale of Buffalo Bill commemorative rifles built by Winchester, which was owned at the time by John Olin. On the market in the late 1960s, the rifles were priced at $\$ 129.95$ with $\$ 5.00$ per rifle going to the BBM. Revenue from the sales of the rifles totaled approximately $\$ 825,000$, enough to build the BBM wing of the Center. ${ }^{1}$

This short history of the funding and the building of the Buffalo Bill Museum raises three important issues. First, by the late 1950s and 1960s, the BBM was designed as an educational institution, a purpose that is reflected today in the institution's mission statement: 'The Buffalo Bill Historical Center is a museum that educates the public by advancing knowledge about the American West through acquiring, preserving, exhibiting and interpreting collections' (J. Hedderman, personal communication, March, 8, 2004). Second, supporters' interests in the museum were primarily national, not local, in scope. The museum was designed to attract audiences from across the nation, and the representations in the museum narrate a story of national significance. ${ }^{2}$ Finally, the museum's location in Wyoming was and is crucial both to its pedagogical mission and its growth into a nationally recognized institution (Nicholas, 2002, pp. 439, 449). As Bartlett (1992) asserts, 'the Historical Center is devoted to the history of the American West, and perhaps no other region in the United States is still so untarnished by modern times, still so genuinely western' (p. 4). The BBHC also interacts with other major sites of memory including Mount Rushmore and the uncompleted Crazy Horse Memorial. Like the BBHC, these memorials draw on and reinforce a discourse of heroism as modes narrating, or, in the case of the Crazy Horse Memorial, resisting the story of the nation (Blair \& Michael, 2004). The Buffalo Bill Museum, then, serves as a pedagogical site, working to teach its visitors about the Old West and in so doing inculcating a particular vision not only of 'the West' but also of what it means to be American. As a social and educational institution, the museum offers, in Benson and Anderson's (1989) terms, constructed and thus structured invitations to meaning (p. 3). The purpose of this paper is to explore these structured invitations. ${ }^{3}$ We turn now to the ways by which museums create these invitations.

\section{History Museums, Public Memory and National Identity}

History museums are a popular way for US Americans to engage the past, and more importantly, they are perceived by the public to be the most trustworthy source of information about the past (Rosenzweig \& Thelen, 1998, p. 21). In interviews conducted by Rosenzweig and Thelen (1998), individuals expressed a belief that history 
museums provide relatively unmediated access to the past-a judgment that does not appear to vary by sex, ethnicity or class (p. 21). The artifacts, images and narratives of the museum are understood to be 'real' and thus reliable markers of the past. Finally, museum visitors feel particularly connected to the past when visiting museums (Rosenzweig \& Thelen, pp. 19-21). As pedagogical institutions, then, history museums are compelling sites.

The perceived truthfulness of history museums, as well as their size, scope and complexity, pose unique challenges for rhetorical critics (Armada, 1998, p. 235). However, such critics, who have increasingly turned their attention to the material spaces of memory (Blair \& Michael, 1999; Blair, Jeppeson, \& Pucci, 1991; Dickinson, 1997; Gallagher, 1999, 1995; Hasian, 2004; Katriel, 1994), are well positioned to understand the suasory force of history museums. Rhetorical critics bring an understanding of the interaction between texts and audiences to these sites. Historians have the tools to argue about the factual accuracy of museums (Loewen, 1999), art critics and art historians can evaluate artifacts in the appropriate aesthetic contexts (Dubin, 1999; Fryd, 1992), and scholars in American Studies are equipped to trace the political and economic forces in creating museums (Nicholas, 2002). Scholars of rhetoric, by contrast, consistently point to the ways that museums make claims on audiences (Armada, 1998; Gallagher, 1995, 1999). Rhetoric's concern with textual invitations therefore turns our attention to the ways material sites engage audiences in compelling historical narratives. Since our focus is on these material expressions, our aim in this section is to identify the three primary rhetorical practices of history museums: collecting, exhibiting, and (re)presenting.

\section{Collecting}

First and foremost, museums engage in the practice of collecting. Exhibit curators seek, locate, archive, preserve and ultimately legitimate certain artifacts (both material and discursive) and not others (Gaither, 1992, p. 61). Since museums 'constantly select and discard from the limitless realm of material memory' (Crane, 2000, p. 9), the appeal to memory is always selective, incomplete and partial. To be collected means to be valued, and, in the case of museums, it means to be valued institutionally (Kavanagh, 1996, p. 6; Zelizer, 1995, p. 224). The BBM's collection of domestic artifacts from Cody's family life as well as its collection of Wild West artifacts selectively values certain elements of Cody's history, namely his status as a born Westerner and as an author of Western history. However, through exclusion, the practice of collecting also erases elements of Cody's life and the history of the West. History museums are, therefore, sites of both remembering and forgetting (Kavanagh, p. 6). In functioning as sites of forgetting, museums have the potential to cleanse, absolve or relieve visitors of painful, conflictual histories. Traditionally, history museums have collected primarily material artifacts, which, unlike oral discourse, anchor the transient character of memory (Blair, 1999, pp. 30-50; Nora, 1989, p. 13; Zelizer, p. 232). Objects are not simply representations of the past, they are concrete fragments of the past, and thus they solidify memory, asserting that this particular past really happened; objects stand as embodied testaments to a 
particular memory (Rosenzweig \& Thelen, 1998, p. 21). It is vital, therefore, that critics attend to the materiality of museums, and to the precise ways that visitors experience and interact with tangible artifacts.

\section{Exhibiting}

In addition to collecting, museums are engaged in the practice of exhibiting - of situating, locating, and (re)contextualizing artifacts in actual spaces. 'Space has always helped define the boundaries of memory' (Zelizer, 1995, p. 223), and the spatial location of the museum as well as the placement of objects and testimonials within the museum work to orient visitors toward the past in particular ways (Hutton, 1993, p. 78). First is the matter of site specificity, which deals with the relation between the site of the gallery and the space unconfined by the gallery. Museums are fashioned by the contents and materials of their physical locations, be they industrial or 'natural' (Suderburg, 2000, p. 4), and thus it matters where memory is activated. Museums are constitutive elements in a larger landscape, a landscape that, as Blair and Michael (1999) argue, offer 'rules for reading' the museum and offer specific subject positions for visitors (pp. 58-59). As we have already suggested, the BBM's location in Wyoming is central both to its existence and to its pedagogical force. Upon entering the museum, visitors are already prepared to learn the lessons of the conquering of the West.

A second concern with exhibition is that of installation, which refers to the practice of placing an artifact in the 'neutral' void of a gallery or museum. In removing an artifact from its original context, the placement of artifacts within a museum necessarily alters their meanings (Armada, 1998, p. 236; Maleuvre, 1999, p. 1). In a museum, an artifact's meaning is shaped by how the visitor arrives at it, by how movement through the museum is organized and directed (Bennett, 1995, pp. 180-186), and by the associations and dissociations fostered by juxtaposition with and proximity to other artifacts (Crane, 2000, p. 4; Suderburg, 2000, p. 5). As our analysis of the BBM suggests, the order of the exhibition creates a certain epistemology of the site, providing visitors with reading strategies to help decode the meanings as they move through the space. Regardless of how the visitors begin their visit in the BBM, they experience artifacts of Buffalo Bill's 'real' life first. Visitors necessarily attend to Buffalo Bill's career as a showman only after learning that Buffalo Bill was a 'real hero', and that this personal history served as the foundation in creating the Wild West. The ordering of the museum, then, asserts that the story Buffalo Bill tells in his Wild West, and, by extension, the story the BBM tells, is but a telling of the way it really was.

\section{(Re)presenting}

(Re)presenting constitutes the third key practice of museums. Through their various modes of display, museum curators and designers, interpret artifacts and render them meaningful. The (re)presentational strategies of museums vary greatly from curiosity cabinets and life-size, dioramic environments to automated voiceovers and televisual presentations. The placards, curator's notes, brochures and exhibit catalogues scattered 
throughout museums further shape the meanings of the artifacts on display. Historically, the display of artifacts in museums has been about separation, spectacle and surveillance, as visitors have 'gazed' at artifacts that are preserved and protected behind rope barriers and glass walls (Bennett, 1995, pp. 59-86). Increasingly, however, museums seeking to foster 'lived experience' with artifacts have featured fully immersive, interactive environments. The United States Holocaust Memorial Museum in Washington, DC, for example, seeks to 'encourage its visitors to reflect upon the moral and spiritual questions raised by the events of the Holocaust as well as their own responsibilities as citizens of a democracy' (Mission statement) by having visitors adopt the personas of Holocaust victims and survivors as they move through the museum. Using simulated environments, modern museums often claim to deliver visitors a more 'authentic' experience of history.

Through the intersecting practices of collecting, exhibiting, and (re)presenting, history museums construct a story of the past-a story that is, above all, about 'identities of people in the present' (Armada, 1998, p. 235), about 'defining who people are and how they should act' (Karp, 1994, p. 4). As key civic and public institutions, argue Appadurai and Breckenridge (1992), 'museums ... represent national identities both at home and abroad [and] ... serve as ways in which national and international publics learn about themselves and others' (p. 44). Museums of Western history-drawing on the centrality of the West to define America and utilizing the rhetorical power of history museums more generally_-are among the most important sites in constructing, disseminating and maintaining national identity, as well as in reminding us what it means to be 'American'. Understanding how history museums promote 'social unity' (Bodnar, 1992, p. 13) even as they struggle to be sensitive to and reflexive about our cultural differences is the task of the next section.

\section{Whiteness, Masculinity and the Carnivilzation of Violence in the Buffalo Bill Museum}

Our analysis of the BBM is based on two weekend-long visits, one in 2002 and one in 2003. The three of us spent well over 20 hours each in the BBHC, devoting much of that time to our exploration of the BBM. During our time in the museums, we took photographs of the exhibits, collected documents provided by the institution, visited the onsite archives and took extensive notes of our observations about the space and the ways the space was used by visitors. We have drawn on email and phone conversations with Josie Hedderman, an administrator of the BBHC, as well as utilized Richard Bartlett's (1992) book From Cody to the world published by the BBHC, the BBHC website, and the Center's pamphlets for background information about the institution. In what follows we employ first person narrative of our first visit in portions of our analysis to emphasize the ways traveling to and through the museum influences the rhetorical force of the site.

Cody, Wyoming and the BBHC are located near the center of the 10,000 square miles that compose the Big Horn Basin. For most visitors, travel to the BBHC takes a significant commitment of time and effort. Indeed, our own initial trip conditioned our 
experience of the Center. We first traveled to the Buffalo Bill Museum from Fort Collins, Colorado, in April of 2002. After seven hours of travel by car, we found ourselves in the middle of Wyoming and deep in the heart of the West. The further northwest we journeyed along State Route 120, the fewer signs of 'civilization' we encountered. By the time we had passed through two consecutive towns with populations of 10, the landscape appeared to us as vast, barren, and uninterrupted (Figure 1). Encompassing nearly 98,000 square miles, Wyoming is geographically the ninth largest state in the country (Profile of general), but has the smallest population of any US state. Surrounded on all sides by open range, the partially clouded sky stretched a seemingly endless distance in every direction. In describing her own response to this landscape, Jane Tompkins (1992) writes:

It is environment inimical to human beings, where a person is exposed, the sun beats down, and there is no place to hide. But the negations of the physical setting-no shelter, no water, no rest, no comfort—are also its siren song. Be brave, be strong enough to endure this, it says, and you will become like this—-hard, austere, sublime. (p. 71)

Like Tompkins' response to the Wyoming plains, our understanding of this landscape as 'the West' is already culturally informed. For over 100 years, Wyoming has served as a central symbol in thinking about the West. In the late nineteenth century, painters and novelists like Fredric Remington and Owen Wister declared Wyoming the last stronghold of Anglo-Saxon America' (Nicholas, 2002, p. 439). These images articulate powerfully with the larger 'Myth of the Frontier' which asserts:

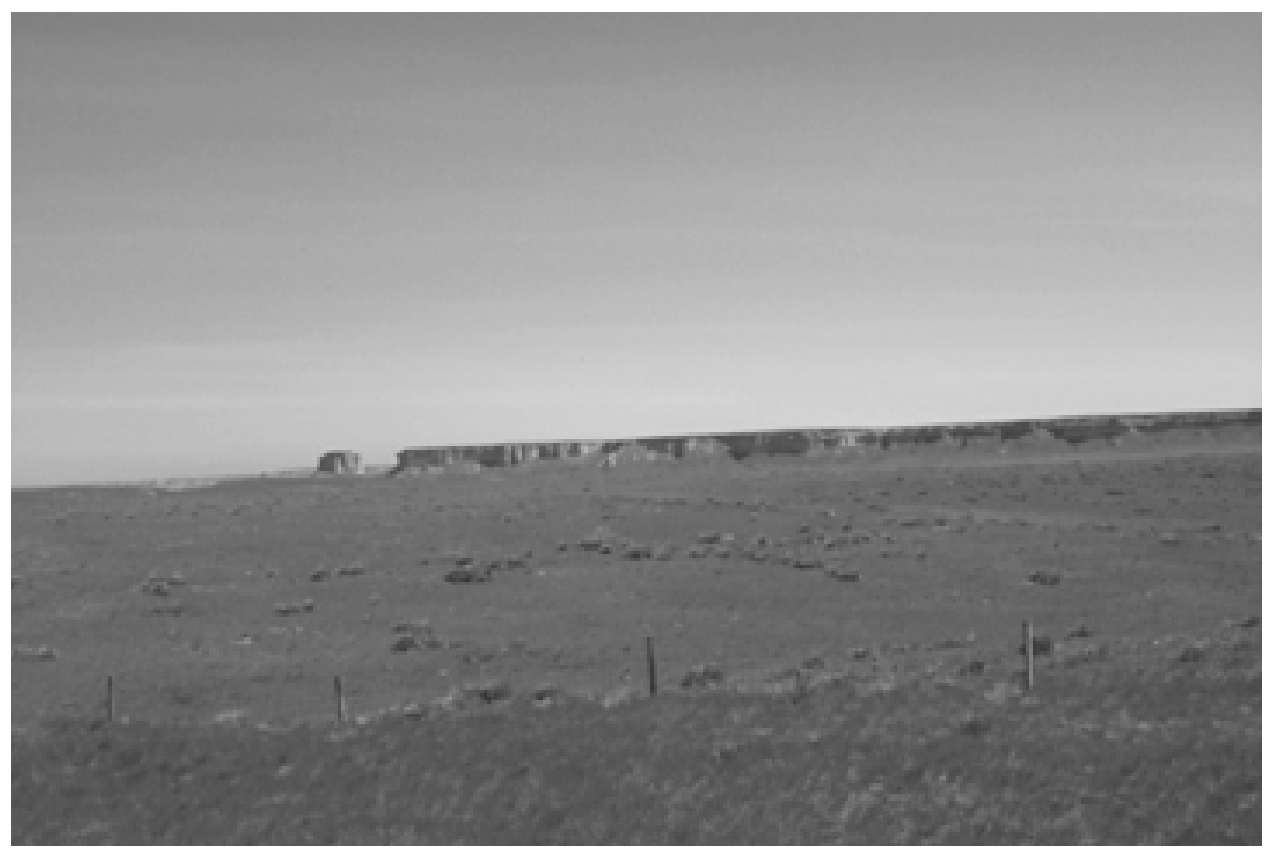

Figure 1 Wyoming Landscape. 
the conquest of the wilderness and subjugation or displacement of the Native Americans who originally inhabited it have been the means to our achievement of national identity, a democratic polity, an ever-expanding economy, and a phenomenally dynamic and 'progressive' civilization. (Slotkin, 1992, p. 10)

In the late nineteenth century, Buffalo Bill, Wyoming's most famous resident, became the ideal embodiment of the frontier hero (Slotkin, pp. 75-76). However, Cody's death did not mark the end of this myth. Indeed, the myth is replayed throughout the twentieth century, and as we will see, serves as a motivating narrative structure of the BBM. The repetition of the myth in movies, novels and political discourse structures our experience of traveling to Cody and the museum.

On our first visit to the Center during the last weekend of April 2002, it was bitterly cold and snow was falling lightly. As we approached the complex, we noticed a large bronze statue of a horse and rider flanking the Center on an adjoining hill. Closer inspection revealed that the impressive $12 \mathrm{ft} 5$ in sculpture was of Buffalo Bill Cody (Figure 2), posed in 'his historic role as a scout, bending down to read the trail while signaling with his rifle' (Treasures, 1992, p. 13). The location of Gertrude Vanderbilt Whitney's Buffalo Bill-The Scout, allows its heroic figure to survey the adjacent valley and mountain range. The statue captures what, at some level, visitors already knowthat they are in cowboy country, in Buffalo Bill's territory, which he austerely oversees with his gaze and gun. We wanted to study the statue more closely, but the cold was unbearable and we proceeded quickly to the Center's entrance. There, a second, and yet very different, statue of Buffalo Bill greeted us (Figure 3). With gun draped casually at his side, Cody tips his hat as if welcoming visitors into his home. Although the BBHC

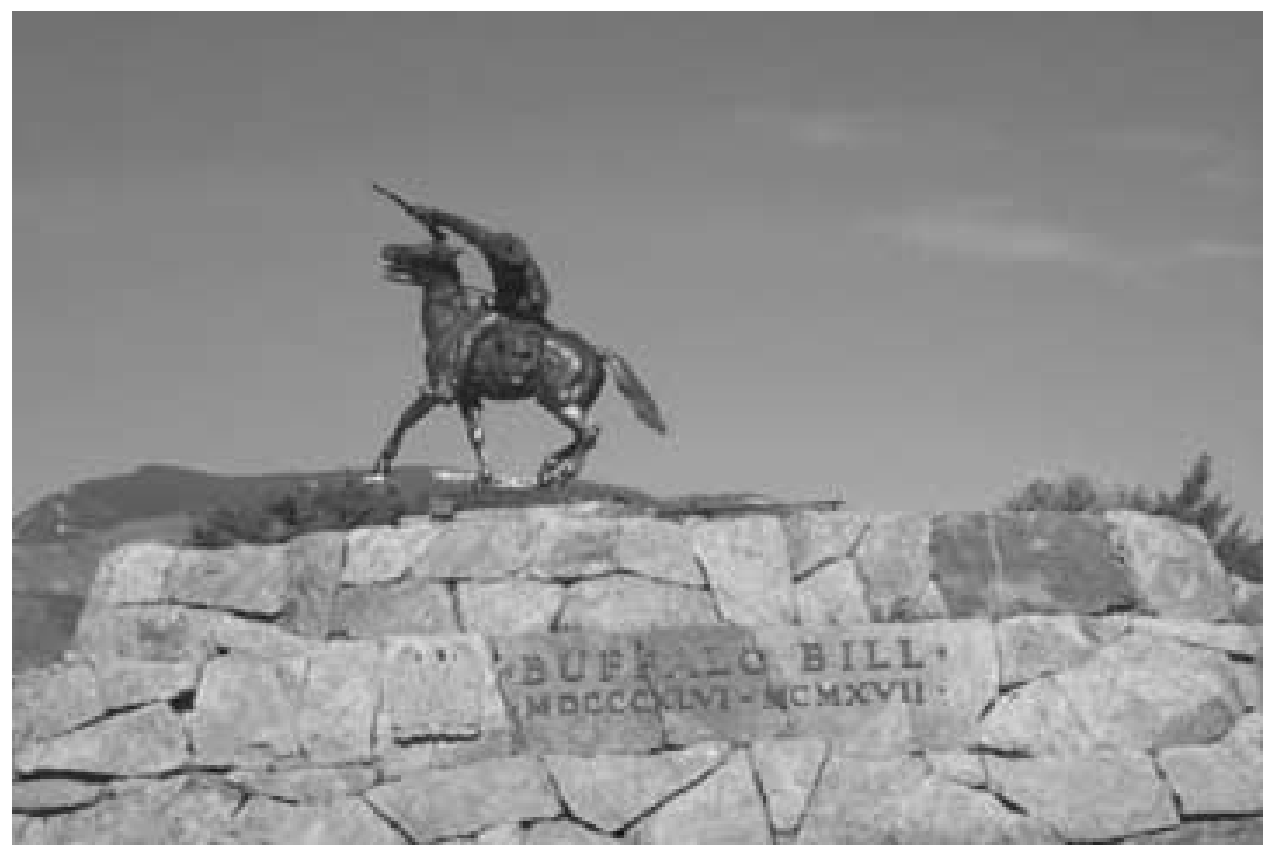

Figure 2 Gertrude Vanderbilt Whitney's Buffalo Bill-The Scout. 


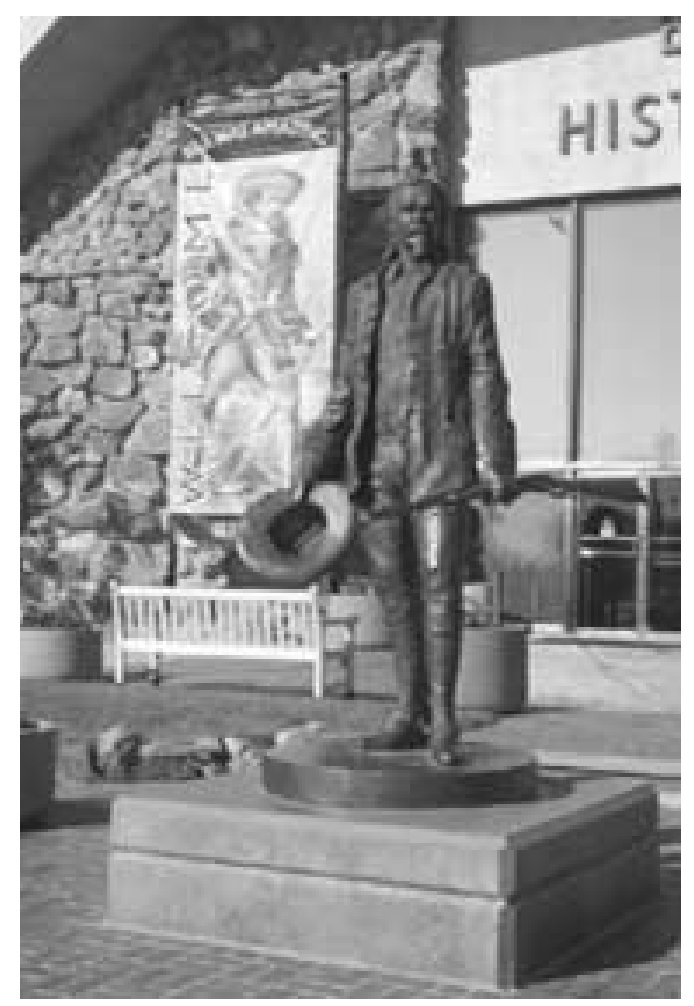

Figure 3 A Bronze Buffalo Bill Greets Visitors.

houses five 'separate' museums, the statues of Cody outside the Center are the first and most obvious of many signs that the story visitors will hear is Cody's to tell. He is both its narrator and chief protagonist.

Having been introduced to the institution's narrator, we entered the BBHC. The space immediately inside the Center, like the landscape that surrounds it, is expansive and airy. After paying our $\$ 15$ admission fee, we found ourselves standing in the center of the 'Orientation Gallery', facing a family of bison grazing on tall range grass (Figure 4). The taxidermied animals are made to appear 'natural', to conceal any human activity and agency in their preservation. As the sole artifact in the Orientation Gallery, the bison perform an important orienting function. They serve to 'naturalize' the story that is just now beginning to unfold, to guarantee that the people and events visitors will learn about were simply colorful features of the landscape and inevitable stages in the natural 'development' of the West. Father, mother and calf affirm a 'natural' history of the West, one of lifecycles, seasonal change and uncorrupted states. The bison obscure the fact that art, whether taxidermied or classical, is not [only] nature but nature existing by and for humans' (Maleuvre, 1999, p. 214). In the accompanying placard, culture is further subordinated to nature, 'The West is a land of symbols: the cowboy, the warrior of the plains, the horse and the six shooter. But perhaps no more representative symbol of the West exists than the American bison, 


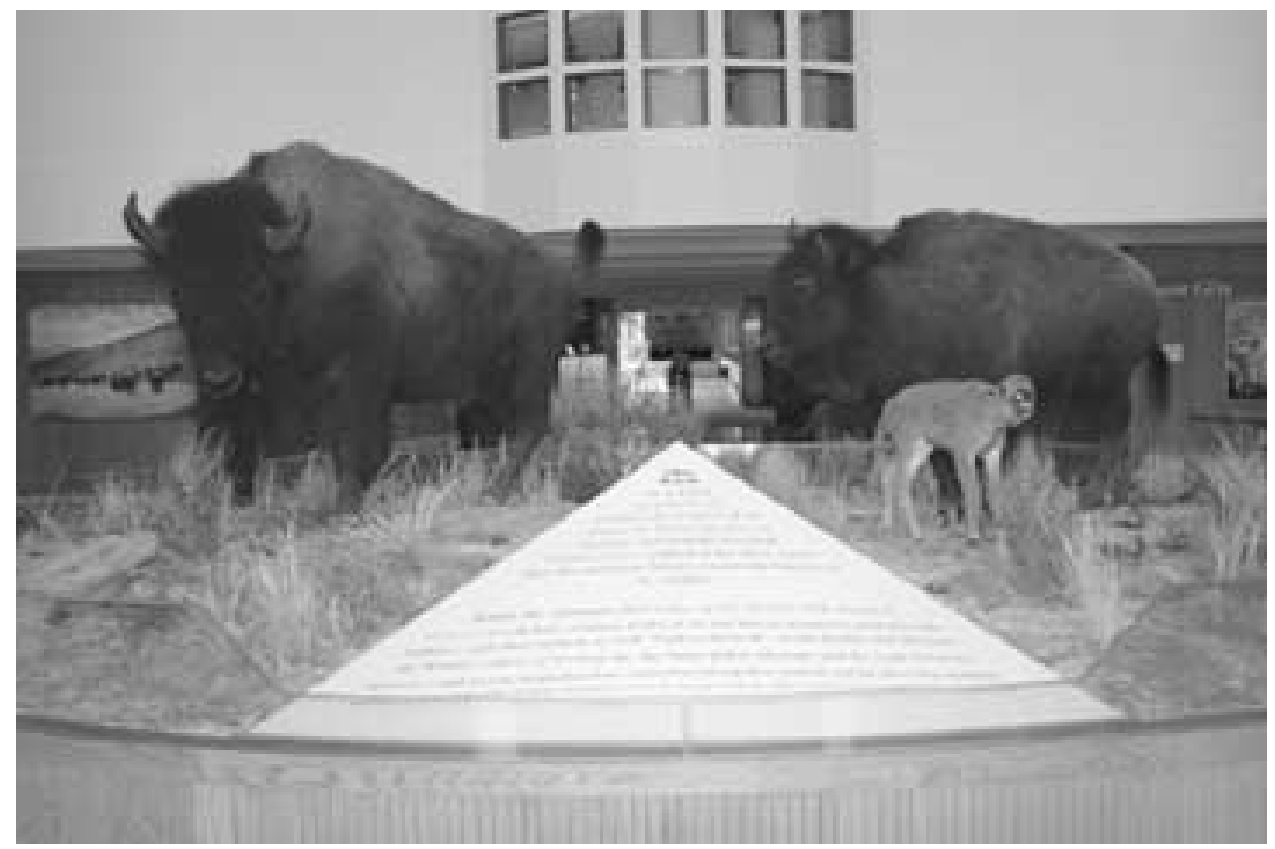

Figure 4 Taxidermied Bison Family.

commonly known as the buffalo'. This installation functions mythically to transform, as Barthes (1972) argues, 'history into nature' (p. 129). The bison, already coded as natural, are stripped of their historical importance as sustenance for Plains Indians and, just as tellingly, are stripped of the history of their violent demise. To dispel any remaining doubt left open by the image of the installation, the placard discursively transforms the bison from their place in historical conflicts into nothing more (or less) than a 'symbol of the West'.

As symbolically important as the buffalo are, even more important is Buffalo Bill and the museum dedicated to his/story. The Buffalo Bill Museum is brightly lit with incandescent and florescent fixtures recessed in the ceiling and the displays. Its space functions rhetorically, like Buffalo Bill's Wild West, '[to] put the epic western experience into an orderly narrative'. The museum is divided into four parts, the Cody Family Room, Local History Room, Wild West Room and Young Buffalo Bill. That these four 'independent' exhibits work to tell a coherent, well-ordered story is evident from the outset. Upon entering the museum, visitors are greeted by a large image of Buffalo Bill in full vaquero stage outfit, sharing his/story with eight captivated children huddled on his lap and at his feet (Figure 5). This same image introduces the BBM in the Treasures from our west (1992) catalogue (p. 9) sold at the gift shop, and a nearly identical image graces the cover of the Center's Visitor's guide. The poster of Buffalo Bill suggests visually what the accompanying placard confirms discursively-that the story is Cody's to tell. 'Buffalo Bill', the placard reads, 'is perhaps best remembered as a storyteller. The story he told — through his life and his show-was heard by millions in America and 


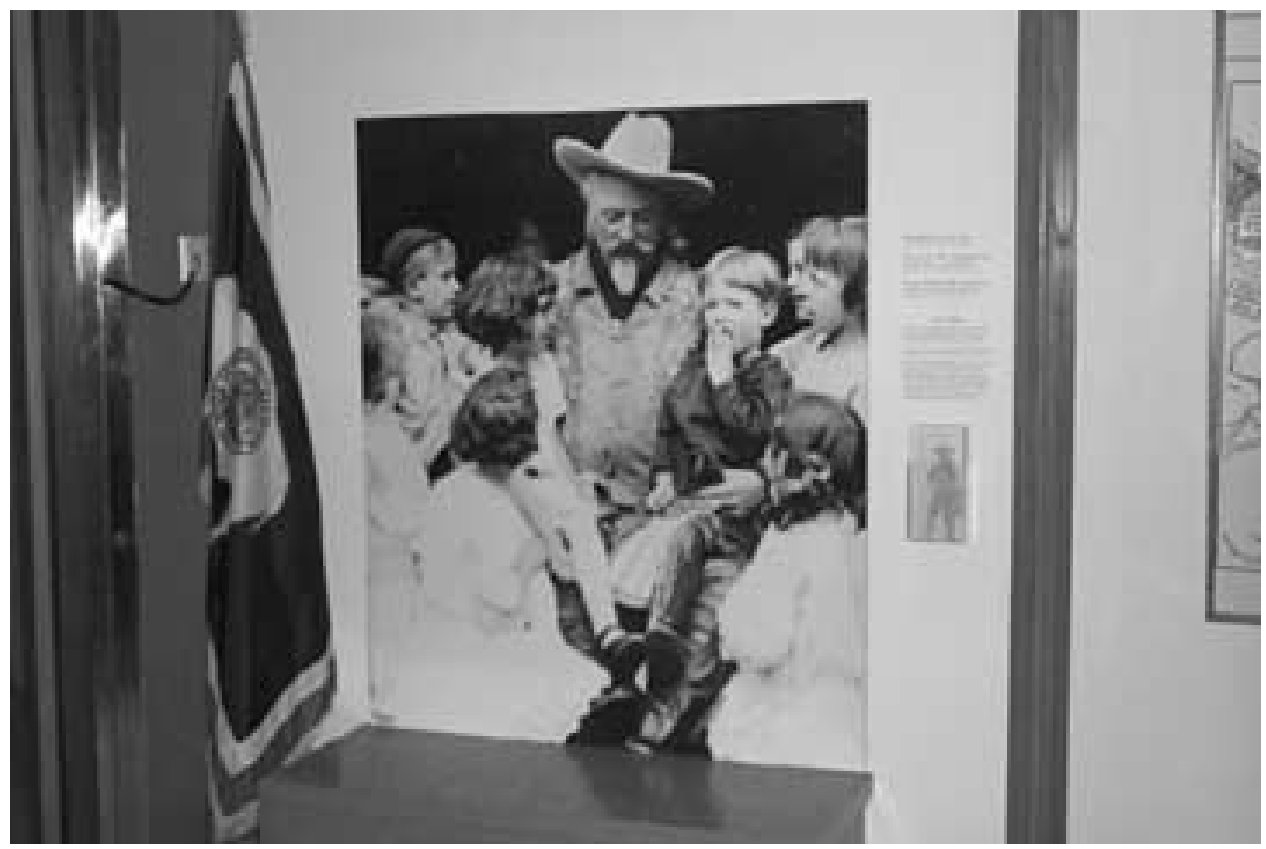

Figure 5 Buffalo Bill, the Storyteller.

abroad. To many of the children and grandchildren of those who saw him, Buffalo Bill is the Wild West' (italics original). In subtly shifting from his role as narrator ('as a storyteller') to his role as participant, as real life Western figure ('through his life and show'), the placard lends credence and authenticity to Cody's history. ${ }^{4}$ Moreover, the closing phrase ('Buffalo Bill is the Wild West') functions synecdochically to suggest that Cody's story is not simply $a$ history, but the history of the West.

The first exhibit, the Cody Family Room, exercises a similar authorizing function. It showcases an array of furniture and personal items from Cody's home in North Platte, Nebraska. The various artifacts from Cody's home materially document his life on the frontier and guarantee that his story of the West is grounded in lived experience. The location of this exhibit prior to the Wild West Room is significant as it frames how visitors come to the showman stage of his life. The spatial layout symbolically suggests that Cody is a Westerner first and that his life as a Westerner is the basis for the (hi)story told in his Wild West 'show'.

In addition to grounding history in lived experience, the Family Room is important because of its definition of family. By unreflectively exhibiting Cody's home as an archetypal example of 'frontier life', the family room naturalizes Whiteness as the invisible center of that life. As there is an entire museum at the BBHC dedicated to the 'cultural backgrounds, traditions, values, and histories' of the Plains Indians (Visitor's guide), it is tempting to dismiss this critique. Locating the culture of the Plains Indians in a separate museum, apart from a generic history of the frontier, however, is precisely the installation practice that decenters the American Indian. The Plains Indian 
Museum claims to reflect a particular set of cultural experiences, while the Buffalo Bill Museum-although utterly silent about its White ethnic bias-claims, according to the membership brochure, to represent the 'culture of the Western frontier' (We're making history). This exclusion of Native Americans from the narrative of Anglo American history is typical of Western histories (Lake, 1991, pp. 124-125; Morris \& Wander, 1990, pp. 165-166). Indeed, with the frontier myth, Native Americans serve as the 'savage' opposite to Anglo-Americans' 'civilization' and culture (Slotkin, 1992, pp. 14-16).

Situated between the Cody Family Room exhibit and the Wild West exhibit is the Local History Room. On our visit, this room was filled with a collection of contemporary 'Western' furniture created by local artisans and furniture makers. The spatial movement through these three exhibits, then, follows a past, present, past temporal structure. The interruption of the past by the present did not seem odd to any of us as we moved through the BBM, and none of us commented on it during our visit. The West of the present seemed to 'fit right in line' with the West of the past-its bulky, rustic, natural all-wood furniture indicating the same strength and ruggedness of character suggested by the artifacts in the Cody Family Room. The movement from past to present to past again is virtually seamless and suggests that the qualities embodied in the artifacts of the Local History Room are a product of place, not time. The West, visitors are told, is timeless, and its unchanging landscape promises a certain (stereo)type of hero. ${ }^{5}$ Judging by the accompanying surnames, the furniture in the Local History Room was created exclusively by artisans of European descent and reflects a collecting practice that, once again, treats White ethnic identity as the invisible norm in Western culture. The exhibit's relative location in the Buffalo Bill Museum as well as its unreflective treatment of White culture as Western culture extends and confirms the story of Western life introduced by the Cody Family Room-a story that begins with and is centered on White Western settlement. The Native American is, thus far, altogether absent from the museum's history of the frontier. Beginning the story when and as it does functions rhetorically to reaffirm 'settlement' myths by treating the land as unoccupied and untamed prior to the arrival of (White) frontiersmen. The Plains Indians come onto the scene only after museum visitors are introduced to typical (read as White and patriarchal) frontier life, and even then they are represented not as an indigenous people, but as one of the 'novelties' and 'challenges' faced by early settlers.

Since the stated purpose of the Buffalo Bill Museum is 'to interpret his [Cody's] story in the context of the history and myth of the American West', and since 'Indians were vital' in Cody's own 'master narrative of the West', it is worth noting that the first and only images of American Indians that visitors encounter in the BBM are in the third exhibit, the Wild West Room. The relegation of Native Americans to the Wild West exhibit suggests that, for the museum, they are peripheral to the history of the American frontier and constructs them primarily as objects of spectacle and entertainment, as an exoticized ethnic Other. The representation of cowboys and Indians in the Wild West exhibit is intriguing because it perpetuates many of the same stereotypes and images as Buffalo Bill's Wild West, even as it carnivalizes the show's foundational trope-that of 
Indian/White violence. ${ }^{6}$ To better understand this partial homology, it is necessary to examine the exhibit's collection and display of artifacts and contrast them with the images and discourses from Buffalo Bill's Wild West. The Wild West Room is composed of three types of museum artifacts: costumes and props from Buffalo Bill's Wild West, a short video of historical footage from the show, and a collection of promotional posters for it.

The Wild West exhibit features an impressive array of costumes and props from Buffalo Bill's actual Wild West (which itself claimed to be presenting the actual history of the West). Visitors are invited to peruse show-related items such as costumes, saddles and firearms. Accompanied by short identifying placards and photographs of Cody in costume (Figure 6), the artifacts in this portion of the exhibit are largely decontextualized. The fringed and beaded buckskin shirts and broad Stetson hats reproduce the (stereo)typical image of the cowboy found widely in popular culture. By tapping into popular images of the cowboy-images that were shaped significantly by Cody's theatrical attire-the costumes serve to affirm Cody's authenticity as a cowboy (Kasson, 2000, p. 40). Completing the familiar image of the cowboy is a collection of firearms from the show, including William 'Doc' Carver's Colt .45 revolver and Annie Oakley's Winchester .32 rifle. ${ }^{7}$ Absent from the exhibit and its history of the frontier is any discussion or analysis of the role firearms played in the slaughter of the buffalo or in the violent conflicts between American Indians and Whites. Instead, the firearms gesture to the sharp shooting skills of individuals like Doc Carver and Annie Oakley, reducing guns to objects of play and aesthetics.

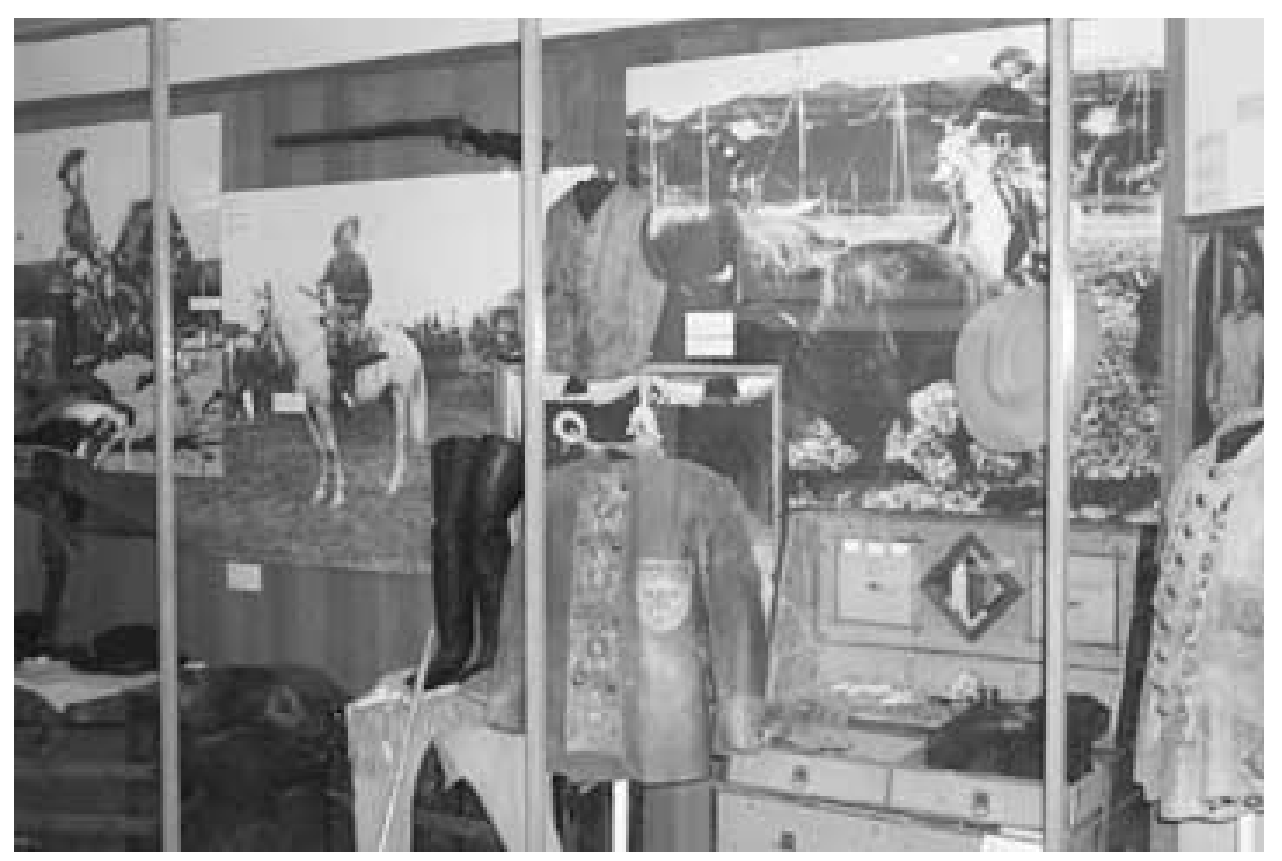

Figure 6 Display of Costumes and Props from Buffalo Bill's Wild West. 
Among the most impressive artifacts from Buffalo Bill's Wild West is the stagecoach (Figure 7) purchased by Cody from the Cheyenne and Black Hills stage line in 1883 to portray Indian stagecoach raids. In Buffalo Bill's Wild West, the 'Attack on the Stagecoach' was one of the many popular skits that told of Indian aggression, White female victimization, and male heroism (White, 1994, p. 27), but the museum does not comment on the political implications of how the stagecoach was used in the show. In failing to contextualize its artifacts or to problematize the Wild West's version of history, the Wild West exhibit perpetuates the show's stereotypical image of the cowboy, while repressing the violence that was a central feature of the show. The Wild West exhibit draws, then, on the narrative of Buffalo Bill's Wild West as its founding story, while the Wild West itself is a founding narrative of the West that continues to haunt US imagination, a narrative simply reinforced by the museum itself (Slotkin, 1992, pp. 81-82).

The only components of the Wild West exhibit in which Indian/White violence is explicitly (re)presented are the Wild West film and promotional posters for the show. In both instances, the images of violence are sparse and heavily coded as 'entertainment'. The video is a short, black-and-white film of actual footage from Buffalo Bill's Wild West. It plays continuously on a small television monitor situated in front of several rows of cushioned benches inside a mock arena canopy. The canopy bears a striking resemblance to the large image of a Wild West 'tent' in a nearby display case and furnishes the space with a carnival atmosphere. The images are grainy and unsteady, giving the film a nostalgic, but clumsy, feel. Thus, the footage of an Indian-led attack on a stagecoach and the passengers' eventual rescue by Buffalo Bill is almost humorous.

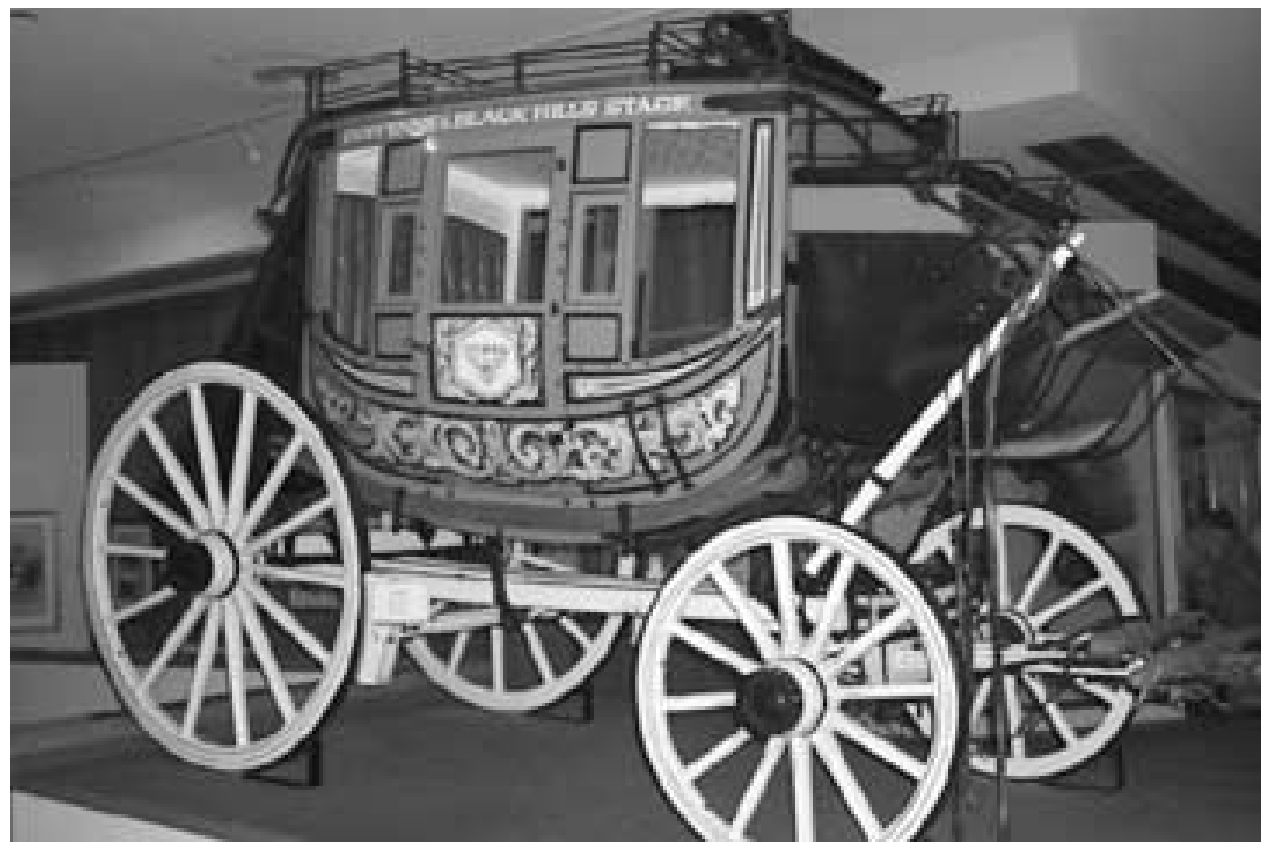

Figure 7 Concord Stage Coach (1867) used in Buffalo Bill's Wild West. 
The image does not, by contemporary standards, seem particularly violent or realistic, and the assemblage of the performers, both 'cowboys and Indians', at the end of the film reminds viewers of its fictional nature.

Several of the promotional posters for the show also depict clashes between Native Americans and Whites, but the depictions are cartoonish in style and do not invite serious reflection on the actual violence that characterized westward expansion. Promotional posters for Buffalo Bill's Wild West are the most prevalent artifacts in the Wild West exhibit, and in some cases, fill an entire wall (Figure 8), but there is no explanation in the museum of what relation the images in the posters bear to history and myth. With no discourse to contextualize the images in the posters, visitors learn more about advertising of the time than about Indian/White relations. In fact, the sole placard dedicated to Wild West posters focuses on the role of posters in nineteenthcentury advertising and the process of stone lithography used to print them. The placard structures the visual images into a story of progress both of technology and of advertising. The slim possibilities for oppositional readings of the White/Native American relationships are displaced into the realm of 'entertainment' and into a discourse of technological and economic development.

The artifacts, video and posters in the Wild West exhibit operate as simulacra. They are images that materially testify only to another set of images (that is, Buffalo Bill's Wild West) for which there is no historical referent. But with no reflection on Buffalo Bill's history of the frontier as told through his Wild West, the engulfing presence of genuine, tangible, precious, historical artifacts fosters the appearance of 'real' history. The near endless photographs of Buffalo Bill, along with the meticulous preservation

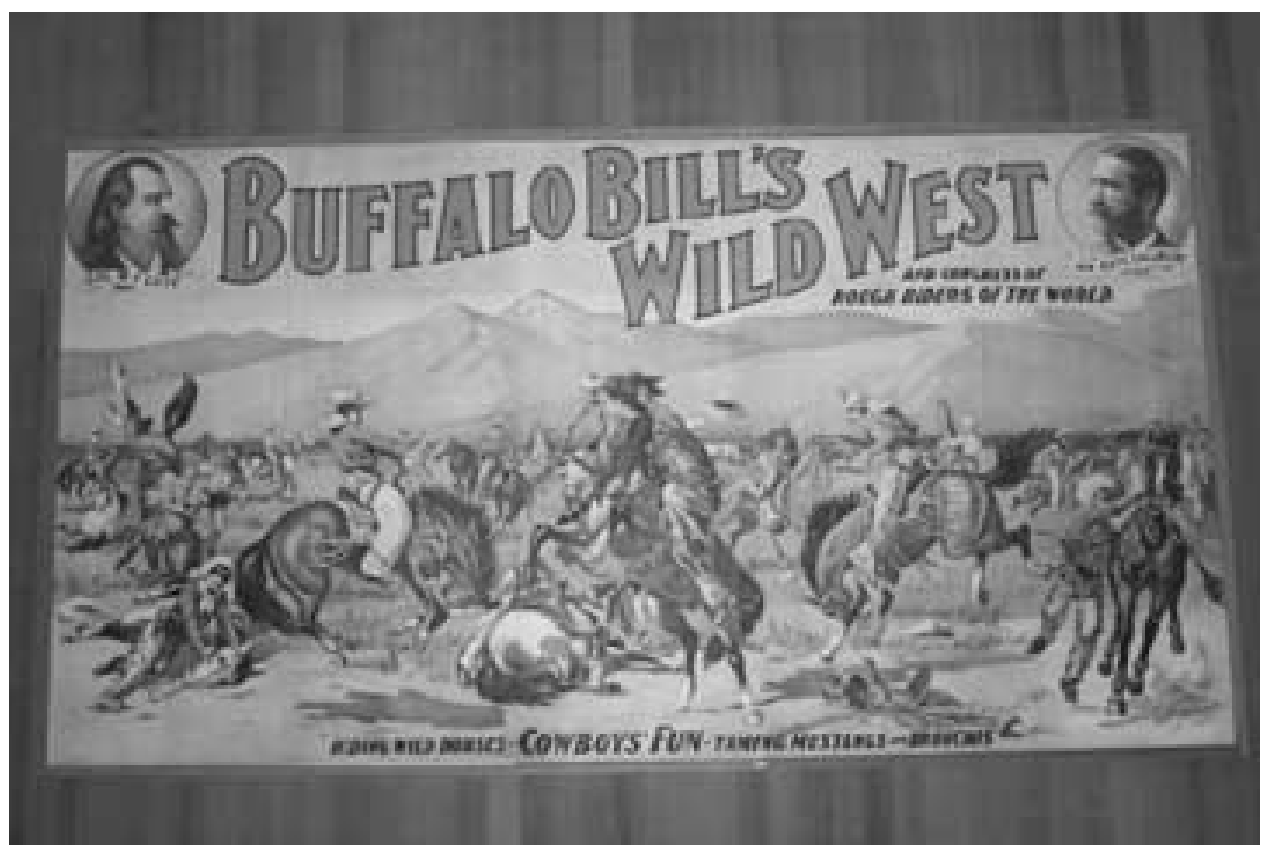

Figure 8 Promotional Poster for Buffalo Bill's Wild West. 
and thus celebration of his clothing, riding equipment and firearms, obscures the fact that 'Buffalo Bill' is himself a fictional, popularly manufactured image of the cowboy. So, by the time visitors reach the final exhibit in the Buffalo Bill Museum, Buffalo Bill seems more real than William Cody and it matters not that Cody's experiences as a Pony Express Rider and Civil War private in the Seventh Kansas Volunteer Cavalry are detailed in an exhibit titled 'Young Buffalo Bill'. Although the experiences and events recounted in this exhibit precede Cody's creation of the Wild West arena show, the Young Buffalo Bill exhibit temporally follows the Wild West exhibit in the museum. As visitors near the exit of the BBM, this historical reversal functions to remind them that Buffalo Bill was not simply a showman, but that he was also a genuine Western hero. ${ }^{8}$ It is here, for instance, that visitors learn Cody was awarded the Congressional Medal of Honor for valor.

There is a sense in which the Cody Family Room and Young Buffalo Bill function for the BBM in the same way as 'real' artifacts of the West functioned in Buffalo Bill's Wild West. In both cases, the authenticity of the artifacts in these exhibits asserts the authenticity of Buffalo Bill as hero and narrator of the West. Both the Wild West and contemporary history museums, including the BBM, garner their trustworthiness in similar ways. Visitors are positioned as though they are in the presence of the 'real' and unmediated elements of the past (Rosenzweig \& Thelen, 1998, p. 21). The 'authenticity' of the BBM, however, is even more complex than that of the Wild West. For here the artifacts from Cody's youth and from his life as a showman are accorded the same kind of historical authenticity. The stagecoach on exhibit is the 'real' stagecoach from the 'real' show, a show that claimed reality based in part on the fact the stagecoach had a pre-show life as a 'real' stagecoach. Visitors, then, engage in both a history of the West and history of the representation of the West, a representation that relied on the authenticity of its props and its hero as justification. The props-already accorded authenticity by Buffalo Bill at the turn of the twentieth century-are given a double authenticity in the museum: they are, at once, authentic markers of the real West and authentic props of the Wild West.

These multiplying levels of authenticity and simulacra cover profound absences. Much of Cody's life story is not told in this exhibit or the museum, such as his reputation as an 'Indian slayer' beginning at the age of 11 (Carter, 2000, pp. 30-32; Croft-Cooke \& Meadmore, 1952, p. 120; Lamar, 1977, p. 230; Nash, 1992, p. 80; Russell, 1960, pp. 214-35), or his role as 'the greatest killer of buffaloes whom the old West produced' (Neider, 1958, p. 219). This absent history is crucial to the museum's rhetoric and more generally to the myth of the frontier (Slotkin, 1992, pp. 13-14). Cody's exploits as Indian and buffalo killer are displaced onto the violent but neutralized images of the Wild West. The violence is not absent, but carnivalized. The posters, the decontextualized attack on the stage coach, the rifles of Annie Oakley and of Doc Carver, all represent an acknowledgement of the violent colonization of the West, but an acknowledgement that continually defers political engagement of the history of western colonization. The BBM, in deferring and carnivalizing Cody's part in the violent conquest of the West, invites visitors to defer their own responsibilities for the violent colonization of the West (Morris \& Wander, 1990, pp. 165-166). 
Dime novels and early biographies about Buffalo Bill were filled with accounts of Indian slaying and buffalo hunting, and Buffalo Bill's Wild West 'made the conquest of savages central [to life on the frontier] ... His spectacles presented an account of Indian aggression and white defense; of Indian killers and white victims' (White, 1994, pp. 11, 27). For Buffalo Bill, the cowboy was a romantic figure, whose heroism was closely tied to his hunting and fighting skills, to his ability live off the harsh land and to fend off the 'savages'. For the BBM, the cowboy remains a romantic, celebrated figure, who-as a placard titled 'The Cowboy,' informs museum visitors-'represents the best in all Americans ... We admire him for his independence, his honesty, his modesty and courage'. To appeal to contemporary audiences the BBM recodes cowboy heroism into categories other than violence. By mid-twentieth-century, after all, public sentiment was shifting. The blind extermination of buffalo at the close of the nineteenth century had nearly caused their extinction and Buffalo Bill's narrative of the frontier with its badly abused (read: White) conquerors was deemed inverted by historians. Thus, the violence so central to Buffalo Bill's life and to the Wild West are replaced by images of Buffalo Bill and stage Indians as entertainers, co-performers, and 'friends'. The cowboy is celebrated for his sharp shooting skills, but only as they relate to glass bobbles; he is praised for his riding and wrangling skills, but only as they relate to ranching. The cowboy remains a hero because he overcame an indomitable setting - a setting that the BBM, in confining Native Americans to the Wild West Room, suggests was his for the taking.

\section{Constructing Public Memory and National Identity: Reflections on White Masculinity, Carnivalized Violence and Manifest Destiny}

The BBM is one site in which the story of the American West is told, one place where the myth of US origins is dramatized and replayed, as such, the BBM draws on and helps constitute larger memory structures for national identity. In this final section we point to these memory structures and suggest the ways the BBM is a crucial institution in the creation of a vision of national identity that rests on White masculinity, carnivalized violence, and manifest destiny.

The Western nation-state and its attendant values of individualism, democracy, selfdetermination, and equality rest on the purposefully forgotten oppressions and rejections of the 'Other.' As scholars have recently argued, European, Anglo, and US American modernities depended on a consistent expansion of Western ways of being, foisting onto the colonized other values of savagery, communalism and domination while reserving for the Western actor the privileged values of civilization, democracy, and freedom (Shome \& Hegde, 2002, p. 254). The colonization of American Indians in the US proceeded differently from many other colonizing discourses. This difference can, in part, be attributed to the ways the US colonization of native peoples occurred within its own geopolitical boundaries allowing the US to represent its 'expansionist motives as essential to nation-building, denying the imperial' (Anderson \& Domash, 2002, p. 126). This nation building colonial impulse was justified, in part, by the rhetoric of manifest destiny, which claimed that westward expansion was not simply 
necessary for political or economic reasons, but was, instead, a moral or even religious duty of the nation. Yet this form of colonization carried with it difficult contradictions. As Anderson and Domash argue, 'the experiences of colonizing internally brings to the fore ... contradictions inherent in national identities forged from positioning the colonized as both them and us' (p. 126). Creating and maintaining US national identity, then, depends on creating stories that negotiate these contradictions, 'stories that deny and assert the presence and significance of internal "others"' (Anderson \& Domash, p. 126).

Implicitly drawing on the language of manifest destiny and suturing itself into the larger myth of the frontier, the BBM enters into these contradictions, representing Buffalo Bill in particular and cowboys more generally as benign heroes who, 'civilize' the land. This civilizing maneuver allows Buffalo Bill to escape the charges of imperial violence under the guise of offering to both Native Americans and Euro Americans an improved and more productive land and life. The museum, through its practices of collection, exhibition and (re)presentation, celebrates the White, male, civilizing colonizer - the one who brings the goods of modern society to an otherwise untamed land (Kirsch, 2002, p. 549; Ollund, 2002, p. 133; Slotkin, 1992, pp. 10-16, 75-76). In this setting Buffalo Bill becomes an ideal hero: White and male, a grand weaver of grand narratives, he tells a story of the West and of America that negotiates the contradictions of internal colonization. The museum is doing much more than simply conveying the biography of a particular cowboy and showman; it is, instead, telling and retelling a narrative of colonization and civilization. In promoting this memory, the museum materially and symbolically constitutes and reconstitutes the modernist story of the US nation state. In motivating this particular memory, the museum draws on and creates the cultural resources not just of the frontier and cowboy myth, but the larger and abstract values of self-determination, rugged individualism, and heroism.

The continuing desire for the BBM's version of Western history is dramatically illustrated by public response to the West as America exhibit at the National Museum of American Art in 1991. That show, whose purpose was 'to critically reexamine received wisdom about American history, intergroup relations, and the American character' (Dubin, 1999, p. 156), became one of the most intensely debated exhibits in museum history. The show's catalog, edited by William H. Truettner, along with the exhibit's placards, consistently highlighted the ideological biases of Western Art (Truettner, 1991; Wolf, 1992, pp. 423-425). Critical responses to the exhibit were swift and vitriolic. After his visit on opening day, historian and Library of Congress librarian emeritus, Daniel Boorstein wrote in the show's notebook: 'A perverse, historically inaccurate destructive exhibit! No credit to the Smithsonian' (quoted in Dubin, p. 160). Commentator Charles Krauthammer, in his Washington Post editorial called the show 'tendentious, dishonest and, finally, puerile' (p. A19). Other commentators argued that the show was the worst of revisionist history and political correctness, undermining fundamental US American values (Dubin, p. 161). Recent academic work interrogating the frontier myth, no doubt, heavily influenced the history of the West presented in the West as America exhibit. Although the exhibit indicates that alternative visions of the West are representable, the resistance to this different vision of the West demonstrates 
the continuing importance of the traditional Western narrative to US American culture.

The BBM offers no 'revisionist' history of the West, nor does not succumb to 'political correctness'. Quite the opposite, in fact, for the heroic narrative told by Buffalo Bill at the end of the nineteenth century returns in the BBM as a story about a story-a fully realized simulacrum (Baudrillard, 1983). ${ }^{9}$ The BBM (re)tells the heroic narrative that celebrates Euro American colonization of the West, while carnivalizing the violence of colonization in a dreamscape of the Wild West. More than simply representing the memory of Cody's entertaining violence, the museum serves as a way for visitors to, at once, acknowledge and avoid the memory of the violence that constructed the west as the 'West'. The memory of violence is transformed into an image of an image; the deathmaking acts constitutive of 'winning' the West become the death-defying tricks of the Wild West. The colonization of the American Indian becomes an hyper-dramatic playa performance that simultaneously enacts and denies the racialized oppressions inherent to the story of the West. This carnivalization and neutralization of the violence of colonization speaks to us not only about our relations with the land and the peoples of the West in the late nineteenth- and early-twentieth century, but also to our understandings of Whiteness, Western colonization, and racialized violence in the twenty-first century.

\section{Notes}

[1] See Bartlett, 1992, pp. 152-154. The museum continues to depend almost exclusively on private financing from entrance fees, donations and grants. State and federal funds have served a minor role in funding this museum (J. Hedderman, personal communication, March, 8, 2004).

[2] See Bartlett, 1992, p. 119. The Center draws visitors from across the country and around the globe. According to the Center's records, visitors come to the Center from nearly every state in the US while less than $5 \%$ of the visitors are from other countries. Most visitors come from the West, in particular California, with Colorado, Texas, Washington, Montana and Wyoming also 'well represented' (J. Hedderman, personal communication, March, 8, 2004).

[3] We will be engaging in a reading of the museum guided primarily by structuralist reading practices. Audiences do not necessarily accept the invitations offered by the text; indeed, some actively resist them. We suggest, however, that history museums may be particularly powerful as structures of meaning. Further, as important as polysemy and resistance are, exploration of preferred meanings and structured invitations remains a crucial component of criticism. The literature on this debate is too large to cover here. For excellent contributions to this debate see Fiske (1986) and Condit (1989).

[4] Museum visitors are further assured of Cody's authenticity by the placard's second paragraph, titled 'Civil Honors', which highlights his relation to other well known historical figures. 'We live in a skeptical age', the placard continues, 'Many people doubt that anyone like Buffalo Bill, particularly a showman, could measure up to the legends. But at the turn of the century, Buffalo Bill was probably the best-known American in the world. He was consulted on western matters by every president from Grant to Wilson. He counted among his friends such artists and writers as Frederic Remington and Mark Twain. He was honored by royalty, praised by military leaders, and feted by business tycoons'.

[5] The notion of a 'timeless' West is evident in a wide variety of discourses throughout the BBHC, such as this quotation from the Treasures from our west (1992) catalogue: 'Cody died in 1917, but he, and the West in which he lived, did not vanish' (p. 8). 
[6] According to White (1994), 'Cody's Wild West told of violent conquest, of wrestling the continent from the American Indian peoples who occupied the land. Although fictional, Buffalo Bill's story claimed to represent a history ... The bullet, the Wild West program declared, was "the pioneer of civilization"' (p. 9).

[7] Annie Oakley, referred to as 'little sure shot' in promotional literature for the Wild West, did not significantly challenge or disrupt the masculine image of the cowboy. She was by far the most famous female performer to participate in 'cowboy activities' such as sharp shooting, bronc riding, and steer roping. 'Women constituted roughly just ten percent of an exhibition's cast' (Wood-Clark, 1991, p. 16), and they were more commonly cast in stereotypically feminine roles such as 'the prairie flower' or 'damsels in distress'.

[8] Bartlett, writing in 1992, continues to connect William Cody and Buffalo Bill through Cody's real life exploits:

Here was a man of humble origin so respected that millionaires vied for the opportunity of entertaining him - and found him as suave and sophisticated as any gentleman born to the purple. Here was a showman who was heeded as a spokesman for the West, for the Indian, and, overseas, for America. Here was a man with a dime-novel reputation who had really earned fame on the frontier as a scout and guide, who could ride with any horseman and shoot with any marksman, and who followed animal tracks and read Indian sign as surely as the fictional Leatherstocking. William Frederick Cody was his real name, but the world knew him best as-Buffalo Bill. (pp. 3-4)

[9] Near the end of his life and in the years after the Wild West was no longer profitable, Buffalo Bill took several farewell tours across the United States. Slotkin (1992) suggests that the appeal of these tours was not so much a nostalgia for the West before its 'closing', but instead a nostalgia for the spectacle of the Wild West (p. 87). This nostalgia for both the West and Wild West is alive and well in the BBM. Indeed, in the museum the difference between the West and the Wild West is slim.

\section{References}

Anderson, K., \& Domash, M. (2002). North American spaces/postcolonial stories. Cultural Geographies, 9, 125-128.

Appadurai, A., \& Breckenridge, C. (1992). Museums are good to think: Heritage on view in India. In I. Karp, C. Kreamer \& S. Lavine (Eds.), Museums and communities: The politics of public culture (pp. 34-55). Washington, DC: Smithsonian Institution Press.

Armada, B. (1998). Memorial agon: An interpretive tour of the National Civil Rights Museum. Southern Communication Journal, 63, 235-243.

Barthes, R. (1972). Mythologies (A. Lavers, Trans.). New York: Hill and Wang. (Original work published 1957)

Bartlett, R. (1992). From Cody to the world: The first seventy-five years of the Buffalo Bill Memorial Association. Cody, WY: Buffalo Bill Historical Center.

Baudrillard, J. (1983). Simulations (P. Foss, P. Patton \& P. Beitchman, Trans.). New York: Semiotext(e).

Bennett, T. (1995). The birth of the museum: History, theory, politics. New York: Routledge.

Benson, T., \& Anderson, C. (1989). Reality fictions: The films of Frederick Wiseman. Carbondale, IL: Southern Illinois University Press.

Blair, C. (1999). Contemporary U.S. memorial sites as exemplars of rhetoric's materiality. In J. Selzer \& S. Crowley (Eds.), Rhetorical bodies (pp. 16-57). Madison, WI: The University of Wisconsin Press. 
Blair, C., \& Michael, N. (1999). Commemorating in the theme park zone: Reading the astronauts memorial. In T. Rosteck (Ed.), At the intersection: Cultural studies and rhetorical studies (pp. 29-83). New York: Guilford Press.

Blair, C., \& Michael, N. (2004). The Rushmore effect: Ethos and national collective memory. In M. Hyde (Ed.), The ethos of rhetoric (pp. 158-196). Columbia, SC: University of South Carolina Press.

Blair, C., Jeppeson, M., \& Pucci, E. (1991). Public memorializing in postmodernity: The Vietnam Veterans Memorial as prototype. Quarterly Journal of Speech, 77, 263-288.

Bodnar, J. (1992). Remaking America: Public memory, commemoration, and patriotism in the twentieth century. Princeton, NJ: Princeton University Press.

Buffalo Bill Historical Center: Best of the West. (2001). Cody Country: Gateway to Yellowstone Park. [Brochure]. Cody, WY: Cody Enterprise Publication.

Buffalo Bill Museum. (1995). [Catalogue]. Cody, WY: Buffalo Bill Historical Center.

Carter, R. (2000). Buffalo Bill Cody: The man behind the legend. New York: John Wiley and Sons, Inc.

Condit, C. (1989). The rhetorical limits of polysemy. Critical Studies in Mass Communication, 6, $103-123$.

Crane, S. (2000). Introduction. In S. Crane (Ed.), Museums and memory (pp. 1-13). Stanford, CA: Stanford University Press.

Croft-Cooke, R., \& Meadmore, W. S. (1952). Buffalo Bill: The legend, the man of action, the showman. London: Sidgwick and Jackson Limited.

Dickinson, G. (1997). Memories for sale: Nostalgia and the construction of identity in Old Pasadena. Quarterly Journal of Speech, 83, 1-27.

Dubin, S. (1999). Displays of power: Memory and amnesia in the American museum. New York: New York University Press.

Fiske, J. (1986). Television: Polysemy and popularity. Critical Studies in Mass Communication, 3, 391-408.

Fryd, V. (1992). Art and empire: The politics of ethnicity in the United States capitol, 1815-1860. New Haven, CT: Yale University Press.

Gaither, E. (1992). 'Hey that's mine': Thoughts on pluralism and American museums. In I. Karp, C. Kreamer \& S. Lavine (Eds.), Museums and communities: The politics of public culture (pp. 56-64). Washington, DC: Smithsonian Institution Press.

Gallagher, V. (1995). Remembering together: Rhetorical integration and the case of the Martin Luther King, Jr. Memorial. Southern Communication Journal, 60, 109-119.

Gallagher, V. (1999). Memory and reconciliation in the Birmingham Civil Rights Institute. Rhetoric and Public Affairs, 2, 303-320.

Hasian, M., Jr. (2004). Remembering and forgetting the 'final solution': A rhetorical pilgrimage through the U.S. Holocaust Memorial Museum. Critical Studies in Media Communication, 21, 64-92.

Hutton, P. (1993). History as an art of memory. Hanover, VT: University of Vermont.

Karp, I. (1994). Introduction: Museums and communities: The politics of public culture. In I. Karp, C. Kreamer \& S. Lavine (Eds.), Museums and communities: The politics of public culture (pp. 1-18). Washington, DC: Smithsonian Institution Press.

Kasson, J. (2000). Buffalo Bill's Wild West: Celebrity, memory, and popular history. New York: Hill and Wang.

Katriel, T. (1994). Sites of memory: Discourses of the past in Israeli pioneering settlement museums. The Quarterly Journal of Speech, 80, 1-20.

Kavanagh, G. (1996). Making histories, making memories. In G. Kavanagh (Ed.), Making Histories in Museums (pp. 1-14). New York: Leicester University Press.

Kirsch, S. (2002). John Wesley Powell and the mapping of the Colorado plateau, 1869-1879: Survey science, geographical solutions, and the economy of environmental values. Annals of the Association of American Geographers, 92, 548-572. 
Krauthammer, C. (1991, May 31). Westward hokum: Political correctness comes to the Smithsonian. The Washington Post, p. A19.

Lake, R. (1991). Between myth and history: Enacting time in Native American protest rhetoric. Quarterly Journal of Speech, 77, 123-152.

Lamar, H. (Ed). (1977). The reader's encyclopedia of the American West. New York: Thomas Crowell Company.

Loewen, J. W. (1999). Lies across America: What our historic sites get wrong. New York: The New Press.

Maleuvre, D. (1999). Museum memories: History, technology, art. Stanford, CA: Stanford University Press.

Mission statement. (2004). The United States Holocaust Memorial Museum. Retrieved March 11, 2003 from http://www.ushmm.org/museum/council/index.utp?content=mission.htm

Morris, R., \& Wander, P. (1990). Native American rhetoric: Dancing in the shadows of the ghost dance. Quarterly Journal of Speech, 76, 154-191.

Nash, J. (1992). Encyclopedia of western lawmen and outlaws. New York: Paragon House.

Neider, C. (Ed). (1958). The great west. New York: Coward-McCann, Inc.

Nicholas, L. (2002). Wyoming as America: Celebrations, a museum, and Yale. American Quarterly, $54,437-465$.

Nora, P. (1989). Between memory and history: Les lieus de mémoire. Representations, 26, 7-24.

Ollund, E. (2002). From savage space to governable space: The extension of United States' judicial sovereignty over Indian country in the nineteenth century. Cultural Geographies, 9, 129-157.

Profile of general demographic characteristics: 2000 (Wyoming). (2002, July 11). U.S. Census Bureau. Retrieved October 31, 2004 from http://factfinder.census.gov/servlet/QTTable?ds_name=DEC_2000_SF1_U\&geo_id=04000US56\&qr_name=DEC_2000_SF1_U_DP1

Rosenzweig, R., \& Thelen, D. (1998). The presence of the past: Popular uses of history in American life. New York: Columbia University Press.

Russell, D. (1960). The lives and legends of Buffalo Bill. Norman, OK: University of Oklahoma Press.

Shome, R., \& Hegde, R. (2002). Postcolonial approaches to communication: Charting the terrain, engaging the intersections. Communication Theory, 12, 249-270.

Slotkin, R. (1992). Gunfighter nation: The myth of the frontier in twentieth-century America. New York: Atheneum.

Sorg, E. (1998). Buffalo Bill: Myth and reality. Santa Fe, NM: Ancient City Press.

Suderburg, E. (2000). Introduction: On installation and site specificity. In E. Suderburg (Ed.), Space, site, intervention: Situating installation art (pp. 1-22). Minneapolis, MN: University of Minnesota.

Tompkins, J. (1992). West of everything: The inner life of westerns. New York: Oxford University Press.

Treasures from our west. (1992). [Catalogue]. Cody, WY: Buffalo Bill Historical Center.

Truettner, W. (Ed). (1991). The West as America: Reinterpreting images of the frontier, 1820-1920. Washington, DC: Smithsonian Institution Press.

Turner, F. (1994). The significance of the frontier in American history. In J. Faragher (Ed.), Rereading Frederick Jackson Turner: 'The significance of the frontier in American history' and other essays (pp. 31-60). New Haven, CT: Yale University Press.

Visitor's guide: Buffalo Bill Historical Center. (2002). [Brochure]. Cody, WY: Buffalo Bill Historical Center.

We're making history 'happen!' (2002). [Brochure]. Cody, WY: Buffalo Bill Historical Center.

White, R. (1994). Frederick Jackson Turner and Buffalo Bill. In J. Grossman (Ed.), The frontier in American culture: An exhibition at the Newberry Library, August 26, 1994-January 7, 1995 (pp. 7-65). Berkeley, CA: University of California Press.

Wolf, B. (1992). How the West was hung, or, when I hear the word 'culture' I take out my checkbook. American Quarterly, 44, 418-438. 


\section{G. Dickinson et al.}

Wood-Clark, S. (1991). Beautiful daring western girls: Women of the Wild West shows. Billings, MT: Artcraft Printers.

Wright, W. (2001). The Wild West: The mythic cowboy and social theory. London: Sage Publications.

Zelizer, B. (1995). Reading the past against the grain: The shape of memory studies. Critical Studies in Mass Communication, 12, 214-239. 